\title{
Unlocking the condoms: The effect on sales and theft
}

\author{
Daniel ASHWOOD, Karen B. FARRIS, Shelly CAMPO, Mary L. AQUILINO, Mary LOSCH.
Received (first version):
15-Sep-2010
}

\begin{abstract}
${ }^{*}$
Community pharmacies may place condoms in locked displays or behind glass, thereby reducing access and consequent use.

Objective: Quantify sales and theft of condoms when condoms were unlocked and removed from behind glass in grocery pharmacies

Methods: Design. In this pilot study, condom displays were unlocked in selected pharmacies for three months. Participants. Eight grocery pharmacies in central lowa agreed to participate. Intervention. Stores provided inventory at baseline, sales/theft thereafter in three monthly reports and sales for the same period one-year earlier. Outcome measures. Descriptive statistics quantified condom theft and sales. Number of pharmacies leaving condoms unlocked after the intervention was determined.
\end{abstract}

Results: Theft varied by pharmacy and ranged from an average of 1.33 boxes (units) per month to 27.33 per month. All stores experienced some increase in sales during the intervention. Two locations decided to re-lock their displays, only one indicated theft as the reason.

Conclusion: After removing condoms from locked displays, more condoms were purchased and stolen from the study pharmacies. Sales outweighed theft in all pharmacies.

Keywords: Condoms. Theft. Pharmacies. Health Services Accessibility. United States.

\section{LIBERANDO LOS CONDONES: EL EFECTO EN VENTAS Y ROBOS}

\section{RESUMEN}

Las farmacias comunitarias pueden situar los condones en estanterías cerradas o detrás de un cristal, reduciendo así el acceso y

consiguientemente el uso.

Objetivo: Cuantificar las ventas y el robo de condones cuando están libres y retirados de detrás de un cristal en las farmacias.

Métodos: Diseño. En este estudio piloto, se abrieron las estanterías de los condones en unas farmacias seleccionadas durante tres meses. Participantes. Ocho farmacias en el centro de Iowa aceptaron participar. Intervención. Las farmacias proporcionaron el inventario al principio, informes de las ventas/robos en los tres meses posteriores y las ventas para ese mismo periodo de un año antes. Medidas de resultados. La estadística descriptiva cuantificó las ventas y robos de condones. Se determinó el número de farmacias que dejaron los condones abiertos después de la intervención. Resultados: Los robos variaron por farmacia y oscilaron entre una media de 1,33 cajas (unidades) por mes a 27,33 por mes. Todas las farmacias experimentaron algún aumento en las ventas durante la intervención. Dos establecimientos decidieron volver a cerrar los expositores de condones, y sólo uno indicó el robo como causa. Conclusión: Después de retirar los condones de los expositores cerrados, se vendieron y robaron más condones en las farmacias estudiadas. Las ventas sobrepasaron los robos en todas las farmacias.

Palabras clave: Condones. Robo. Farmacias. Accesibilidad a Servicios Sanitarios. Estados Unidos.

\section{INTRODUCTION}

Assistant, Program in Pharmaceutical Socioeconomics, College of Pharmacy, University of lowa. lowa City, IA (United States).

Karen B. FARRIS. PhD. Charles R. Walgreen III Professor in Pharmacy Administration and Professor of Social \& Administrative Pharmacy, Department of Clinical, Social \& Administrative Sciences, College of Pharmacy, University of Michigan. Ann Arbor, MI (United States).

Shelly CAMPO. PhD is. Associate Professor. Department of Community and Behavioral Health, College of Public Health, University of lowa. lowa City, IA (United States). Mary L. AQUILINO. PhD, FNP. Clinical Associate Professor. Department of Community and Behavioral Health, College of Public Health, University of lowa. lowa City, IA (United States).

Mary LOSCH. PhD. Professor. Center for Social \& Behavioral Research, University of Northern lowa. Cedar Falls, IA (United States).
Approximately half of all pregnancies in the U.S. are unintended. ${ }^{1}$ One issue contributing to unintended pregnancies is lack of access to contraception which includes availability, affordability, insurance coverage, transportation and convenience. ${ }^{2,3}$ Pharmacies are one retail outlet where nonprescription contraceptives tend to be readily available and may be purchased. However, items in U.S. pharmacies that are high cost or subject to theft may be kept in areas where store personnel can easily view the item and the shopper or locked away. ${ }^{4}$ Among lowa pharmacies responding to a fax survey, over 90 percent of independent, $82 \%$ of small/large chain and $58 \%$ of mass 
merchandise/supermarket pharmacies kept condoms on open shelves: seven percent of small/large chain and $13 \%$ of mass merchandise/supermarket pharmacies kept condoms behind locked glass. ${ }^{5}$ With condoms locked, one can assume these items are perceived as liable to theft as they are not generally high cost items. This theft perception is likely based upon a pharmacy's past experience and/or the past experience of pharmacy staff.

Placing condoms behind locked glass is an access barrier to this nonprescription contraceptive product and it likely impacts their important public health role in reducing unintended pregnancy and offering protection against sexually transmitted infections. While product placement of condoms has been explored $^{6}$, little research on the effect of unlocking displays has been published. What research has shown is a positive relationship between condom availability and use. ${ }^{7,8}$ Therefore, if one can assume that locking condoms reduces the availability then unlocking them may increase their use and improve public health outcomes. The aim of this pilot study was to quantify theft and sales of condoms when condoms were unlocked and removed from behind glass in grocery pharmacies. If theft is not problematic, then future studies can further explore this idea and work to increase condom access in pharmacies.

\section{METHODS}

Design. This pilot study was a 3-month intervention that used a prospective, observational design in 8 grocery pharmacies with data from one-year previous serving as the control for each participating pharmacy. The glass from the contraceptive displays was removed, thus unlocked, and sales and theft were measured for each individual store. The University of lowa institutional review board stated that no approval was necessary for this study because no information on human subjects was obtained; only store level data were collected. Pharmacies were reimbursed for any theft of condoms during their participation in this study.

Participants. A large Midwestern grocery chain with pharmacies was utilized for this study. Eligible stores were identified by location in two lowa cities. Eighteen pharmacies were located in the study area, and six were ineligible because five stores reported their condoms were already in displays that did not have locked glass, and one store had contraceptives in individual clear plastic security boxes, similar to those used with DVDs and CDs. Four stores declined to participate because they were too busy or they wanted corporate orders to participate. This resulted in eight stores participating in the study or a $66.7 \%$ participation rate of eligible pharmacies.

All pharmacies were located in one of two cities in lowa, separated by 25 miles. According to 2000 Census data, one city had a population of $\sim 125,000$ and the median household income was USD43,704 and per capita money income was USD22,589. In this city, individuals under age 5 represented $7.1 \%$ of the population, under age 18 was $24.5 \%$ and 65 years old or over was $13.1 \%$. The percent of persons below poverty was $7.5 \%$. The second, smaller University town had a population of almost 63,000 , with a median household income of USD34,977 and per capita money income of USD20,269. In this smaller city, individuals under age 5 represented $4.6 \%$ of the population, under age 18 was $16.2 \%$ and 65 years old or over was $13.1 \%$. The percent below poverty was $7.0 \%{ }^{9}$

For convenience to pharmacy personnel, the time of initiation of the intervention was decided by the store. To account for seasonal sales of condoms by month, sales data for the same months of the intervention a year prior were obtained for each pharmacy. All stores began the intervention (removed the glass) within the first week of meeting with the researcher, and all stores initiated the study in October or November 2008 and continued for 3 months.

Measures. For these 3 months, each store monitored sales (movement) by their existing electronic point of sales (POS) system. This system scans barcodes as items are sold and retains data on how much movement occurs within the store. Theft was monitored by a staff member in each store checking for any missing inventory not accounted for by movement. The numbers of products that were not in inventory and could not be accounted for through movement were considered lost to theft. Stores provided either itemized monthly reports about condom movement or provided summary tables from their electronic POS system. Reports included inventory, sales, and theft. Each box of condoms, regardless of the number of condoms in each box, was reported as one unit. Due to store desire to not have their prices visible to other stores in competition, no pricing or cost data is presented here.

Analysis. Stores had variable beginning inventories because they were different sizes. To account for this variation, the percent of theft out of inventory for each store was calculated. Average theft for each of the months was calculated. Average increase of sales during the intervention was also calculated. Only descriptive data are presented and tests of statistical significance were not used because of the low sample size.

\section{RESULTS}

In total, 176 units were stolen over 3 months from all 8 pharmacies. Theft varied by store and ranged from an average of 1.33 to 27.33 units per month. The average theft over 3 months was 7.33 units per month. One pharmacy experienced a much higher amount of theft than the other pharmacies (Figure 1). The average overall theft excluding this outlier was 4.48 units per month.

The average percent of theft from inventory for all locations over the three months was $3.96 \%$. Pharmacy 4 remained the store with highest theft with $13.87 \%$ of their inventory stolen the first month and $11.74 \%$ stolen during the last month. Other stores of note were pharmacy 5 and 7 . Pharmacy 
5's highest amount of theft was $8.22 \%$ during one month and Pharmacy 7's highest percent of theft was $9.62 \%$ for the one month that they experienced theft.

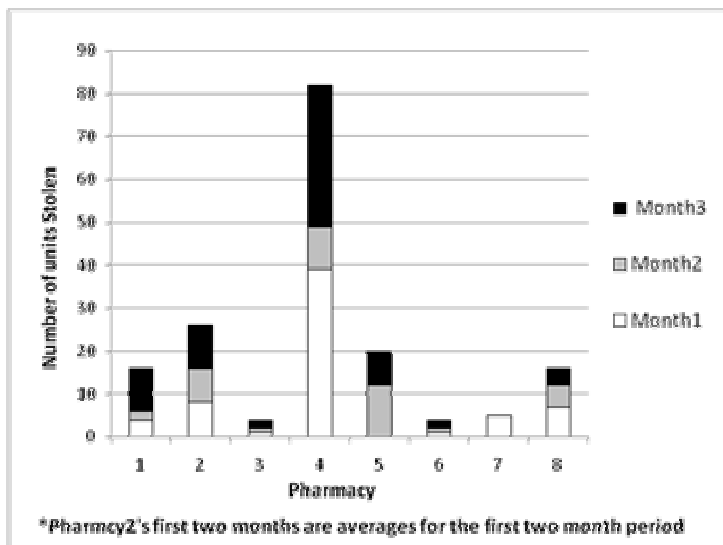

Figure 1. Theft over three months.

Unlocking the condoms produced an increase in sales over the three months of the intervention for all but one pharmacy; pharmacy 7 . The average increase for the three months of the intervention was 9.37 units per month. The number of units leaving each store, through sales as well as theft, again varied by pharmacy (Figure 2).When compared to the corresponding months a year prior, every pharmacy experienced an increase in sales (Figure 3). The pharmacy with the highest amount of theft also experienced the highest increase in sales; pharmacy 4. The average net gain (subtracting the theft from the increase in sales from the previous year) was 4.89 units per month.

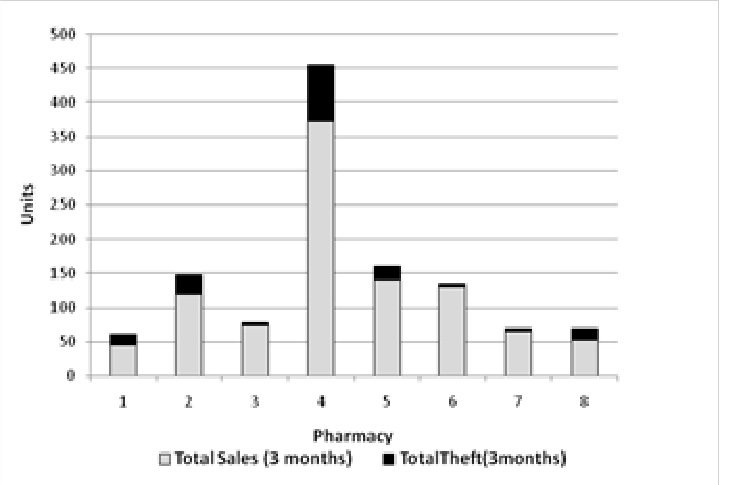

Figure 2. Total units leaving each pharmacy.

Two locations decided to re-lock their displays after the intervention. Only one location indicated theft as the reason; pharmacy 4 . The other location (even though experiencing relatively low theft) mentioned possible concern over future theft as the reason; pharmacy 1.

\section{DISCUSSION}

Improved access either through increases in sales or theft occurred when the condoms were unlocked in the 8 study pharmacies. One pharmacy had significantly higher sales as well as theft than the other study pharmacies and this may have been due to its location in a city with a high percentage of
University students. While all pharmacies experienced an increase in sales from the past year, future studies may focus on why a pharmacy would re-lock their display even when they observed little theft in their store. Based on the total theft observed in this study we may conclude that for most stores, condoms are a somewhat low theft item.

Social context regarding the sale of contraceptives, including manager's personal values, past history in the pharmacy and social stigma, may explain the decision of pharmacy 1 to re-lock. However, previous literature has shown stigma that does exist around condom sales to be from the purchasers' experiences. For both men and women, embarrassment has been linked to an awareness of other people being nearby when selecting or purchasing condoms. ${ }^{10,11}$ This fact coupled with other research showing embarrassment to be a hindrance to purchasing condoms ${ }^{12-14}$ makes locking condoms, and therefore requiring the purchaser to ask someone to unlock the display, a regrettable practice.

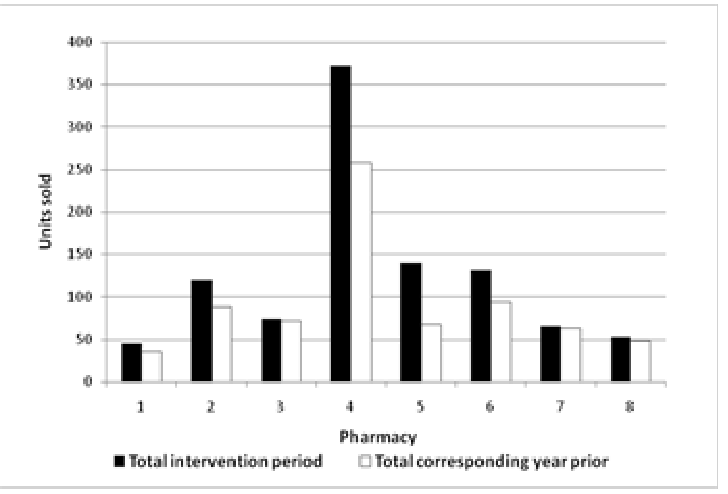

Figure 3. Sales comparison of intervention period and one year prior.

This pilot study suggests that removing condoms from locked displays increases their access. Larger studies over longer periods of time and using a control group are needed to confirm the causal relationship between unlocking displays and the increased sales/theft of condoms. Further research at the store level is also needed to understand the motivation to lock displays in the face of limited theft.

One limitation of this study is that no measure of theft prior to the intervention was possible because the pharmacies were not closely monitoring theft. Pharmacies were not randomly selected for this study. In fact, random selection may not be possible in larger studies as types of pharmacies, namely mass merchandise, grocery and chains, are more likely to place condoms in locked displays. Recruitment of all eligible pharmacies into larger studies may be necessary but a stronger study design would be useful. Arguably one can assume little to no theft was occurring for the products behind locked glass prior to the study. Some pharmacies had the displays open during the day and locked them at night, and these pharmacies may have been experiencing some theft. These 
data do not represent the individual number of condoms sold or stolen, as the number of packages, irrespective of package size, were tracked.

\section{CONCLUSIONS}

Sales increased from the prior year in every pharmacy, with the largest increase occurring in the pharmacy also experiencing the most theft. With condoms being products that are designed both to reduce unintended pregnancy and prevent the spread of certain STIs, it is regrettable that these relatively inexpensive products may be placed behind locked glass. By unlocking these displays, more condoms left the grocery pharmacy and it is reasonable to assume that utilization therefore increased as well.

\section{CONFLICT OF INTEREST}

Drs. Campo, Farris and Aquilino and Mr. Ashwood received grant support from the University of Northern lowa for a subcontract titled Community Pharmacist's Role in Improving Reproductive Health in lowa. At the time of this work, Dr. Farris was Professor, University of lowa College of Pharmacy lowa City, IA. No other conflicts of interest are known.

Portions of the findings in this study were presented in a podium presentation entitled Unlock the Condoms: A Study of Increasing Contraceptive Access in Pharmacy at the American Public Health Association Annual Meeting \& Exposition, Philadelphia, PA, Nov 7-11, 2009.

\section{References}

1. Finer LB, Henshaw SK. Disparities in Rates of Unintended Pregnancy in the United States, 1994 and 2001. Per Sex Reproductive Health. 2006;38:90-96.

2. Landau SC, Tapias MP, McGhee BT. Birth control within reach: a national survey on women's attitudes toward and interest in pharmacy access to hormonal contraception. Contraception. 2006;74:463-470.

3. Brewer J. Reasons for unprotected intercourse in adult women. J Women Health. 2007;16:302-310.

4. Desselle SP, Zgarrick DP. Pharmacy Management: Essentials for all practice settings. 2nd Ed. McGraw Hill Medical, New York, 2009.

5. Schwemm AK, Aquilino MA, Farris KB. lowa pharmacists' attitudes and practices concerning unintended pregnancies.Journal lowa Pharmacists Association 2010;Oct/Nov/Dec:33-9 (peer-reviewed section).

6. Scott-Sheldon LAJ, Glasford DE, Marsh KL, Lust SA. Barriers to condom purchasing: Effects of product positioning on reactions to condoms. SocSci Med. 2006;63:2755-2769.

7. Blake SM, Ledsky R, Goodenow C, Sawyer R, Lohrmann D, Windsor R. Condom availability programs in Massachusetts high schools: Relationships with condom use and sexual behavior. Am J Pub Health. 2003;93:955-962.

8. Cohen DA, Farley TA, Bedimo-Etame JR, Scribner R, Ward W, Kendall C, Rice J. Implementation of condom social marketing in Louisiana, 1993 to 1996. Am J Pub Health. 1999;89(2):204-208.

9. Iowa QuickFacts from the US Census Bureau, Accessed at http://quickfacts.census.gov/qfd/states/19000.html, January 25, 2011.

10. Dahl DW, Gorn GJ, Weinberg CB. The impact of embarrassment on condom purchase behavior. Can J Pub Health. 1998;89:368-370.

11. Dahl DW, Manchanda RV, Argo JJ. Embarrassment in consumer purchase: The roles of social presence and purchase familiarity. J Cons Research. 2001;28:473-481.

12. Gerrard M, Gibbons FX. Sexual experience, sex guilt, and sexual moral reasoning. J Personality. 1982;50:345-359.

13. Helweg-Larsen M, Colins BE. The UCLA multidimensional condom attitude scale: Documenting the complex determinants of condom use in college students. Health Psyc. 1994;13:224-237.

14. Mendelson S. Condoms: A marketing dilemma. Supermarket Business. 1995;50:57-58. 